\title{
Article \\ Cryptomphalus aspersa Eggs Extract Potentiates Human Epidermal Stem Cell Regeneration and Amplification
}

\author{
Lucía San Juan ${ }^{1}{ }^{(0}$, Isabel de Pedro ${ }^{1}$, Azahara Rodríguez-Luna ${ }^{2, *(\mathbb{D}}$, María Villalba ${ }^{3}$, Antonio Guerrero ${ }^{2}$, \\ Salvador González ${ }^{4}$ and Alberto Gandarillas $1,5, *$ (D) \\ 1 Cell Cycle, Stem Cell Fate and Cancer Laboratory, Institute for Research Marqués de Valdecilla (IDIVAL), \\ 39011 Santander, Spain; 1sanjuan@idival.org (L.S.J.); isabeldepedrogonzalez@gmail.com (I.d.P.) \\ 2 Innovation and Development, Cantabria Labs, 28043 Madrid, Spain; antonio.guerrero@cantabrialabs.es \\ 3 Medical Affairs Department, Cantabria Labs, 28043 Madrid, Spain; maria.villalba@cantabrialabs.es \\ 4 Department of Medicine and Medical Specialties, Alcalá de Henares University, 28805 Madrid, Spain; \\ salvador.gonzalezr@uah.es \\ 5 INSERM, Languedoc-Roussillon, 34394 Montpellier, France \\ * Correspondence: azahara.rodriguez@cantabrialabs.es (A.R.-L.); agandarillas@idival.org (A.G.)
}

check for

updates

Citation: San Juan, L.; de Pedro, I.; Rodríguez-Luna, A.; Villalba, M.;

Guerrero, A.; González, S.;

Gandarillas, A. Cryptomphalus aspersa Eggs Extract Potentiates Human Epidermal Stem Cell Regeneration and Amplification. Cosmetics 2022, 9, 2. https://doi.org/10.3390/ cosmetics 9010002

Academic Editors: Carmen

Garcia-Jares and Laura Rubio

Received: 26 November 2021

Accepted: 20 December 2021

Published: 23 December 2021

Publisher's Note: MDPI stays neutral with regard to jurisdictional claims in published maps and institutional affiliations.

Copyright: (c) 2021 by the authors Licensee MDPI, Basel, Switzerland. This article is an open access article distributed under the terms and conditions of the Creative Commons Attribution (CC BY) license (https:// creativecommons.org/licenses/by/ $4.0 /)$.

\begin{abstract}
Modern life and extended life expectancy have prompted the search for natural compounds alleviating skin aging. Evidence supports the beneficial effects on skin integrity and health from the topical administration of preparations of the mollusc Cryptomphalus aspersa eggs extract (IFC-CAF ${ }^{\circledR}$ ) and suggests these effects are partly derived from an impact on skin renewal and repair mechanisms. The objective was to dissect in vitro the specific impact of IFC-CAF ${ }^{\circledR}$ on different parameters related to the regenerative potential, differentiation phenotype and exhaustion of skin stem cells. A prominent impact of IFC-CAF ${ }^{\circledR}$ was the induction of stratification and differentiated phenotypes from skin stem cells. IFC-CAF ${ }^{\circledR}$ slowed down the cell cycle at the keratinocyte DNA repair phase and, decelerated proliferation. However, it preserved the proliferative potential of the stem cells. IFC-CAF ${ }^{\circledR}$ reduced the DNA damage marker, $\gamma \mathrm{H} 2 \mathrm{AX}$, and induced the expression of the transcription factor p53. These features correlated with significant protection in telomere shortening upon replicative exhaustion. Thus, IFC-CAF ${ }^{\circledR}$ helps maintain orderly cell cycling and differentiation, thus potentiating DNA repair and integrity. Our observations support the regenerative and repair capacity of IFC-CAF ${ }^{\circledR}$ on skin, through the improved mobilization and ordered differentiation of keratinocyte precursors and the enhancement of genome surveillance and repair mechanisms that counteract aging.
\end{abstract}

Keywords: skin homeostasis; Cryptomphalus aspersa eggs extract; keratinocyte differentiation; proliferation exhaustion; genome surveillance; cell cycle; p53; telomere maintenance; cell aging

\section{Introduction}

Skin damage and aging and its comorbidities (cancer, atopia) is a constant challenge to public health in modern societies, enhanced by heterogeneous sources of ultraviolet (UV) or ionising radiation and thousands of novel xenotoxins. The skin 'exposome' fosters cumulative damage (lipid and DNA oxidative damage, altered extracellular matrix composition), against which natural reserves for physiological repair exist. An important component of these repair mechanisms is embodied by skin stem cells, capable of renewing epidermal skin layers through ordered, stratified differentiation to render a healthy, functional skin barrier [1]. However, the aging process targets these repair mechanisms. Loss of proteostasis surveillance, decrease in genome repair fitness, and reduced reserves of tissue niches with renewal potential are hallmarks of exposome-induced damage and aging [2,3].

Together with boosting antioxidant/defence pathways [4], the leveraging on natural repair and regeneration mechanisms is a priority target for preventive therapeutic interventions [1,5]. A number of natural sources with beneficial effects on skin integrity and health have been explored [6-10]. Crymtophalus aspersa, a widespread species of the 
Helicidae mollusc family, produces secretions whose topic use improves integrity and fosters repair in aged skin [1]. This complex natural substance includes potent antioxidant molecules [11] that facilitate human dermal fibroblast proliferation and extracellular matrix remodelling [1,12] and improve wound healing and skin repair after aggressions such as acute ionising radiation [12-15]. The cellular or molecular mechanisms of action underlying these properties are still to be investigated.

Here, we report on the specific impact of IFC-CAF ${ }^{\circledR}$, an extract from C. aspersa eggs, on different aspects of the regenerative potential of human primary keratinocytes of the skin, using organotypic systems informative for physiological events in epidermal differentiation and architecture. Our observations show that, while proliferation is not accelerated, but is rather slowed down, IFC-CAF ${ }^{\circledR}$ promotes the engagement of genome integrity surveillance mechanisms and differentiation programmes leading to ordered stratified epithelia. Furthermore, we observed a reduction in telomere shortening in in vitro keratinocyte aging models upon exposure to IFC-CAF ${ }^{\circledR}$. Our studies support the specific therapeutic activities of IFC-CAF ${ }^{\circledR}$ via mobilization and protection of stem cell populations and skin regeneration through promoting physiological differentiation, together with activation of mechanisms counteracting genome damage.

\section{Results}

\subsection{Evaluation of IFC-CAF ${ }^{\circledR}$ Impact on Primary Keratinocyte Proliferation}

To assess whether IFC-CAF ${ }^{\circledR}$ influences skin repair and regeneration by modulating stem cell proliferation, we conducted colony formation assays. We seeded human primary keratinocytes at low density in a fibroblast feeder layer [16] and we tested the impact of IFC-CAF ${ }^{\circledR}$ after a six-day treatment. In these conditions, only stem cells give rise to large, proliferative colonies, whereas cells committed to differentiate give rise to small tiny colonies (about 32 cells) and differentiating cells give no colonies at all [16]. While the lower concentrations of IFC-CAF ${ }^{\circledR}(0.1-0.3 \mathrm{mg} / \mathrm{mL})$ had a modest impact on the proliferative potential of epidermal stem cells, the higher concentration $(0.9 \mathrm{mg} / \mathrm{mL})$ reduced proliferation $(\sim 40 \%)$ and increased the relative proportion of differentiated colonies by 2.5 -fold (Figure $1 \mathrm{~A}, \mathrm{~B})$.

A

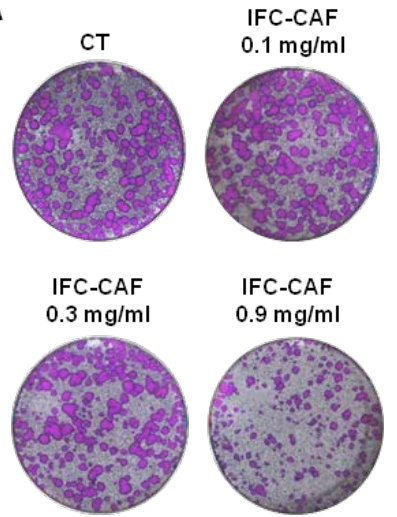

B

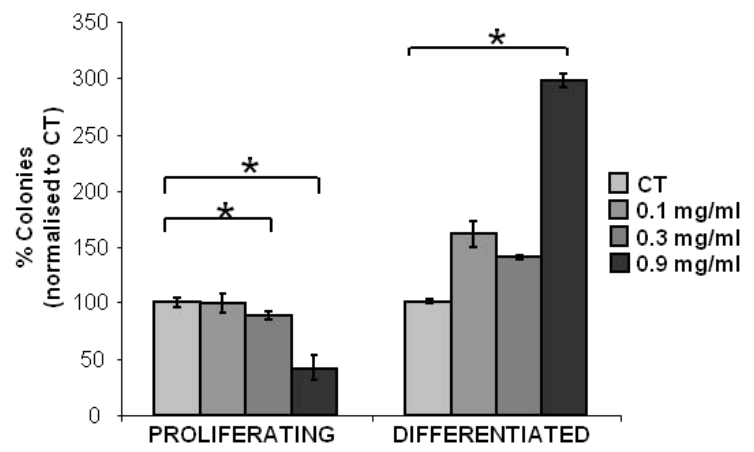

Figure 1. IFC-CAF ${ }^{\circledR}$ delays colony growth of human primary epidermal stem cells. (A) Representative clonogenicity assays across the indicated conditions, stained with Rhodanile blue after 12 days of treatment. Ct: control cultures with the same dilution of the vehicle. (B) Results from two independent experiments are summarised as a percent of colonies belonging to each phenotypic category, across the four indicated conditions and normalised to the Ct cultures. Statistical significance was assessed by the Student's $t$ test (*: $p<0.05$ vs. Control).

These observations suggest that the modulation of skin stem cell proliferation is not a predominant effect contributing to the regenerative and repair enhancement observed in models of damaged skin healing by IFC-CAF ${ }^{\circledR}$ [13]. Importantly, the effects induced above by IFC-CAF ${ }^{\circledR}$ were reversible, as exposure to even the same doses did not have a detrimental 
effect on the proliferative potential of stem cells in subsequent subcultures (Figure 2A,B). Therefore, toxicity or stem cell exhaustion was negligible at all tested concentrations.
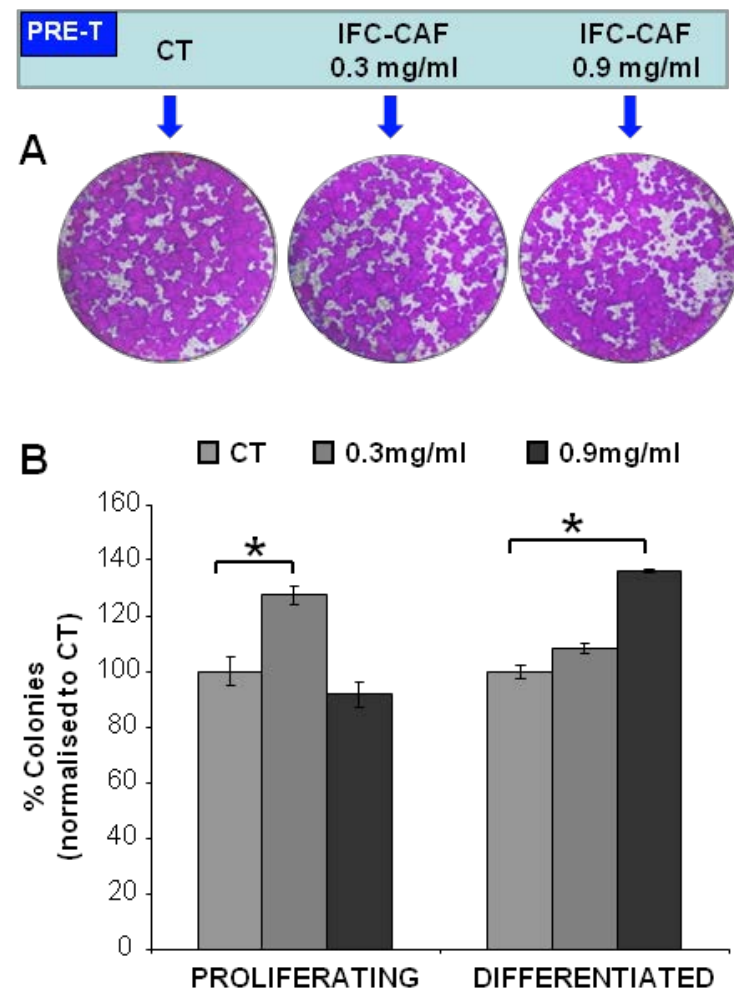

Figure 2. IFC-CAF ${ }^{\circledR}$ preserves the clonogenic potential of primary epidermal stem cells. (A) Representative clonogenicity assays with keratinocytes that were pre-treated (PRE-T) for 6 days as indicated and then seeded, cultured for 15 days in the absence of IFC-CAF ${ }^{\circledR}$ and stained with Rhodanile blue (B) Results from three independent replicates are summarised as a percent of colonies belonging to each phenotypic category, across the three indicated conditions and normalised to the $\mathrm{Ct}$ cultures. Statistical significance was assessed by Student's $t$ test $\left({ }^{*}: p<0.05\right)$.

\subsection{IFC-CAF ${ }^{\circledR}$ Promotes Epidermal Formation In Vitro}

We next studied the effect of IFC-CAF ${ }^{\circledR}$ treatment on the differentiation potential of primary keratinocytes in organotypic cultures, which recapitulate physiological features of stratified growth and architecture of epidermal stem cells [17]. We first quantified the expression levels of involucrin, a well-established marker of epidermal differentiation [18], by either flow cytometry (Figure 3A) or fluorescence microscopy upon immunostaining of primary keratinocytes grown in the presence or absence of IFC-CAF ${ }^{\circledR}$ (Figure 3B). Exposure to $0.9 \mathrm{mg} / \mathrm{mL}$ of IFC-CAF ${ }^{\circledR}$ significantly increased the proportion of cells expressing involucrin by $\sim 20 \%$ over control levels. In addition, the degree of the expression in suprabasal cells was strikingly higher, indicating that IFC-CAF ${ }^{\circledR}$ improved differentiation programmes in epidermal stem cells (Figure 3B,C). Furthermore, analyses of 3D reconstructions from confocal imaging stacks demonstrated that the activation of epidermal differentiation programmes occurs in the context of stratified layers, potentiating vertical cell migration in a physiological fashion (Figure 3C). These observations suggest that the mobilization of skin stem cells for ordered differentiation and regeneration of epidermal architecture might be a predominant component of the effect of IFC-CAF ${ }^{\circledR}$ on the skin. 
A

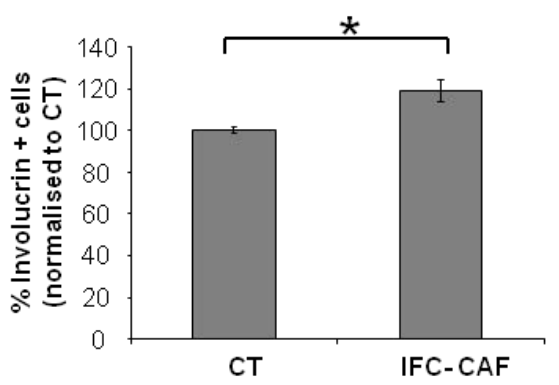

B

七
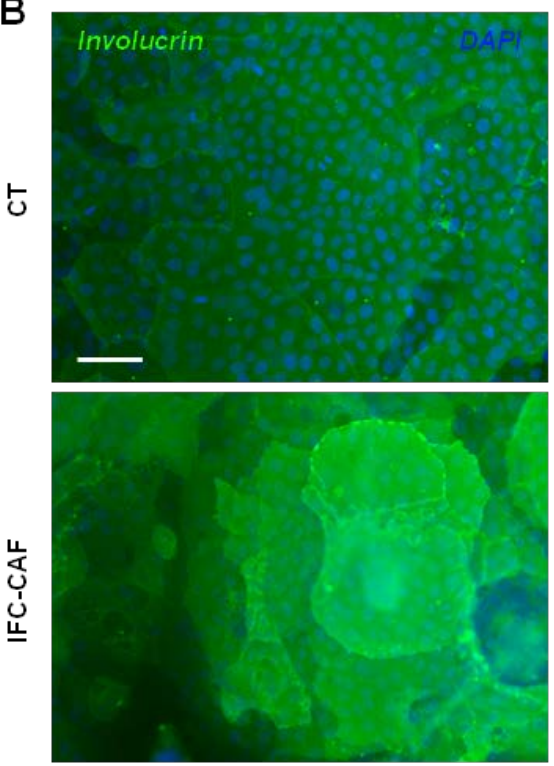

C
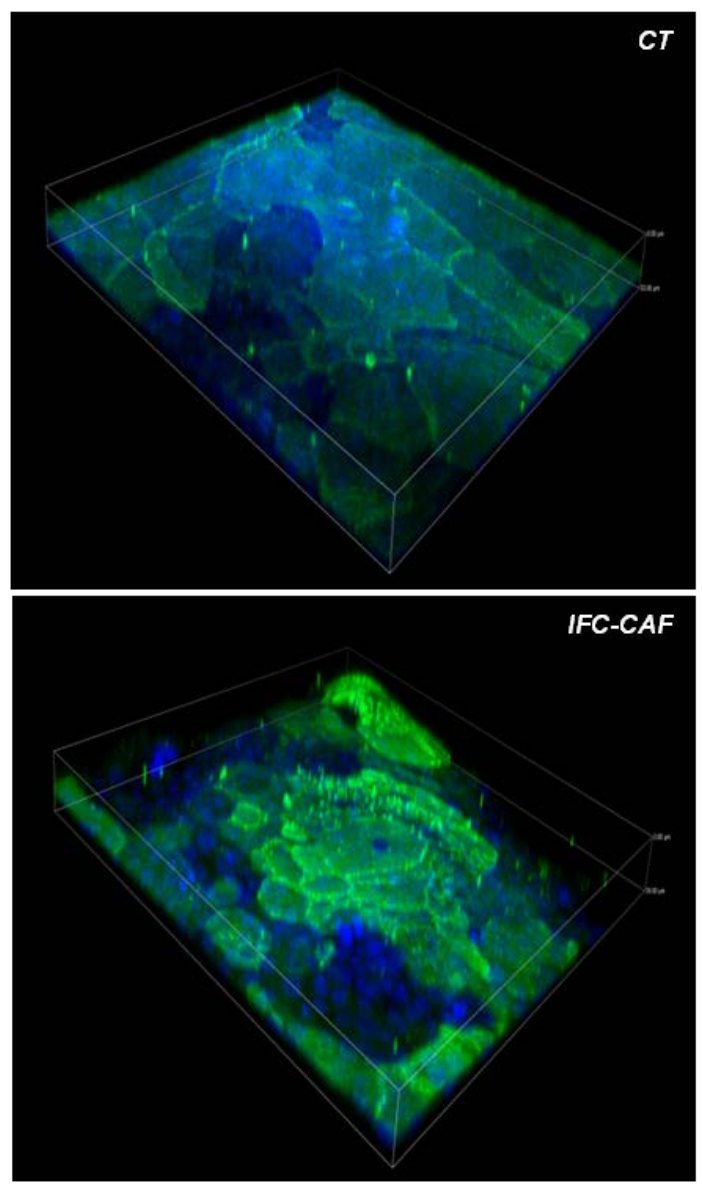

Figure 3. IFC-CAF ${ }^{\circledR}$ promotes vertical epidermal growth and tissue regeneration by stem cells. (A) Flow cytometry analyses of cells either untreated or exposed to IFC-CAF ${ }^{\circledR}(0.9 \mathrm{mg} / \mathrm{mL})$ for 6 days. Percent of positive cells is computed, considering positivity an integrated signal significantly above background (IgGs negative control). Data are mean \pm S.D. of duplicate samples representative of two independent experiments. Statistical significance was assessed by Student's $t$ test $\left.{ }^{*}: p<0.05\right)$. (B) Confocal immunofluorescence microphotograph of primary keratinocytes treated as in (A); green fluorescent signal corresponds to involucrin and DAPI (blue) was used to visualise nuclear DNA. Scale bar: $50 \mu \mathrm{m}$. (C) Representative 3D reconstruction of vertical serial optical confocal sections of involucrin/DAPI labelling, of samples in (B), with same colour code. Z-axis depth: $33 \mu \mathrm{m}$.

2.3. IFC-CAF ${ }^{\circledR}$ Slows Progression through the Keratinocyte G2/M Cell Cycle Transition and Activates Genome Integrity Surveillance Pathways

Because $0.9 \mathrm{mg} / \mathrm{mL}$ IFC-CAF ${ }^{\circledR}$ delayed clonal expansion, we studied in higher detail the keratinocyte cell cycle (Figure 4A,B). Cell cycle profiling of asynchronous cultures exposed to $0.9 \mathrm{mg} / \mathrm{mL}$ for 6 days exhibited reduced G1/S subpopulations ( $5 \%$ ) and a significant increase in G2/M cells ( 10\%), as compared to untreated cultures (Figure 4A,B; $p<0.05)$. Cells accumulated mainly in the G2 fraction of the cycle. Importantly, we did not observe the accumulation of apoptotic sub-G1 populations, further ruling out any cytotoxic effects (Figure 4A). This is consistent with the above observations that IFC-CAF ${ }^{\circledR}$ did not affect the potential of the stem cells (Figure 2). 
A

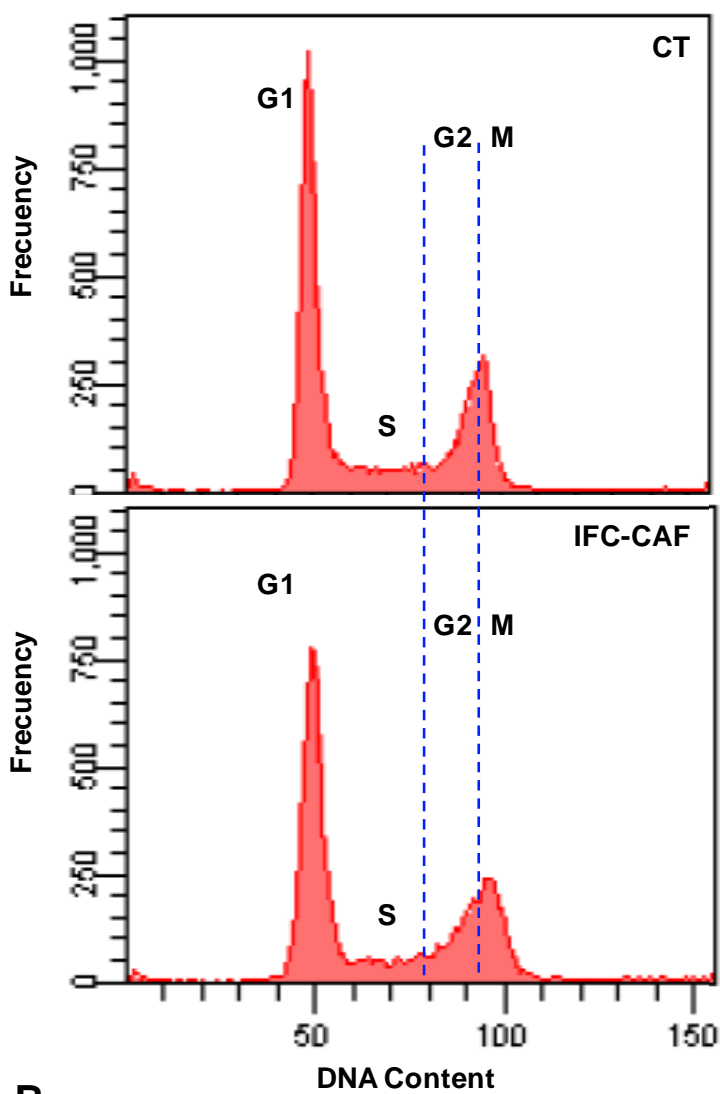

B

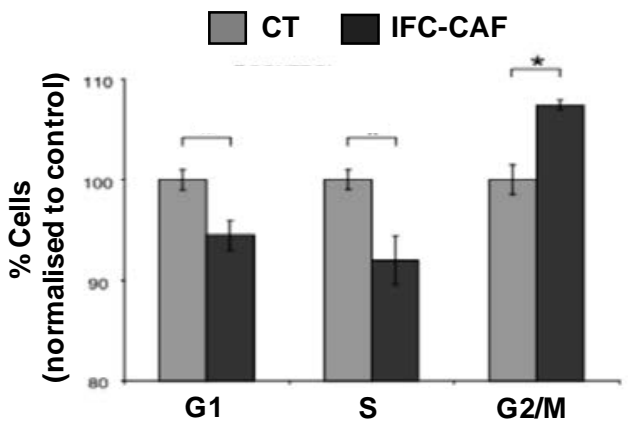

C

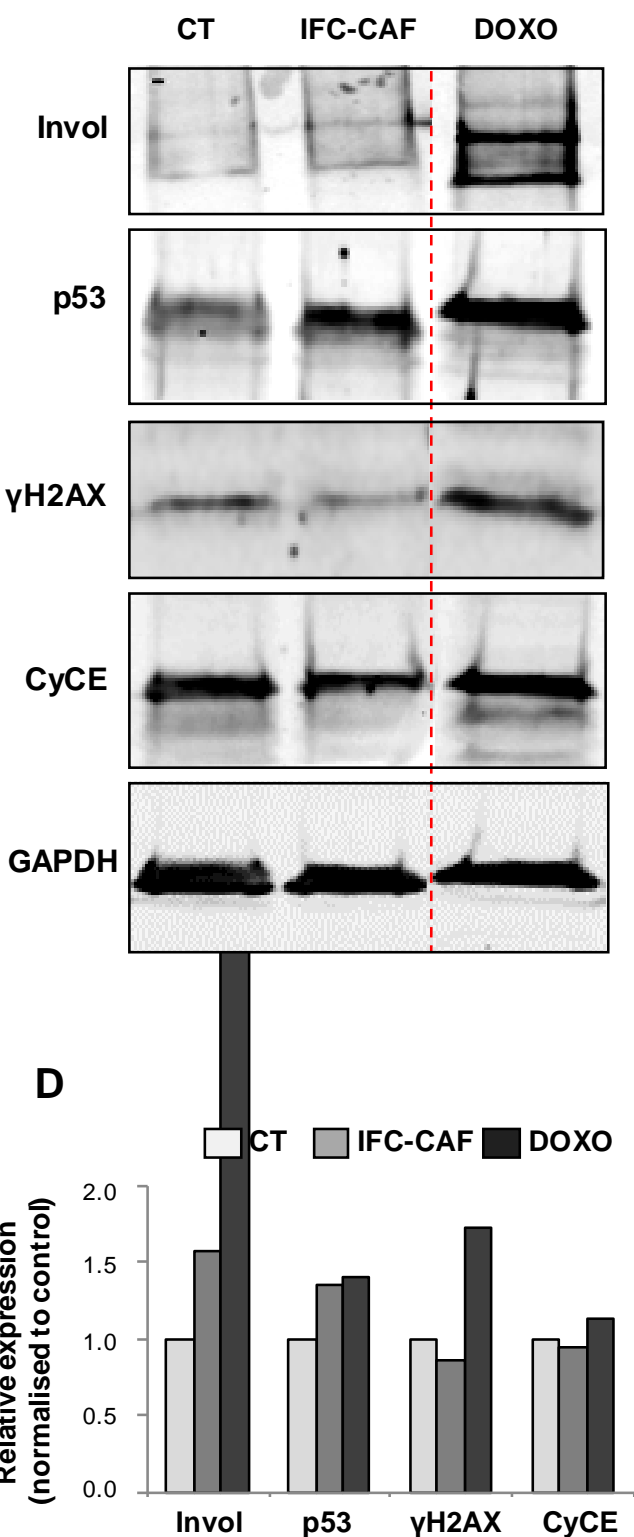

Figure 4. IFC-CAF ${ }^{\circledR}$ slows down the progression of epidermal keratinocytes through the G2/M transition of the cell cycle and promotes the expression of p53 (A) Representative histogram plots of DNA content of asynchronous primary keratinocyte cultures exposed to $0,9 \mathrm{mg} / \mathrm{mL}$ for 6 days. (B) Quantitation of cells across cell cycle phases, untreated (CT) or 6 days after treatment with $0.9 \mathrm{mg} / \mathrm{mL}$ IFC-CAF ${ }^{\circledR}$. Data are derived from two independent biological assays with triplicate samples. Statistical significance was assessed by Student's $t$ test $\left({ }^{*}: p<0.05\right)$. (C) Western blot analyses of cell protein extracts for the indicated markers (Invol: Involucrin; CyCE: Cyclin E), for primary keratinocyte cultures either untreated (CT), exposed 6 days to $0.9 \mathrm{mg} / \mathrm{mL}$ IFC-CAF ${ }^{\circledR}$ (IFCCAF) or treated with doxorubicin (DOXO), as indicated. (D) Densitometric quantification of protein bands in (C) as normalised to CT (invol; same number of cells loaded) or to CT and GAPDH (p53, $\gamma \mathrm{H} 2 \mathrm{AX}$ and $\mathrm{CyCE}$; same amount of protein loaded; GAPDH as loading control).

The results above suggested that IFC-CAF ${ }^{\circledR}$ supplementation favours events leading to cell cycle stalling at the G2 phase-a feature compatible with the engagement of genome integrity surveillance/repair mechanisms $[18,19]$. We further investigated this hypothesis by profiling molecular markers. We assessed by western blot the expression levels of p53 (DNA integrity surveillance), Cyclin E (CycE; drives DNA replication), $\gamma \mathrm{H} 2 \mathrm{AX}$ 
(early signal of DNA damage [20]) and involucrin (marker of keratinocyte differentiation) (Figure 4C). As a positive control of the response of these pathways to genotoxic insult, primary keratinocytes were treated with doxorubicin (DOXO), a well-established DNA intercalating agent used as a chemotherapeutic for the treatment of cancer. DOXO induced a robust, acute stalling of the cell cycle due to compromised DNA integrity (Figure 4C,D). We observed increased levels of $\mathrm{CycE}$, p53 and $\gamma \mathrm{H} 2 \mathrm{AX}$. Keratinocytes exposed to IFC-CAF ${ }^{\circledR}$ also up-regulated p53 and involucrin. However, consistently with a more ordered cell cycle imposed by p53, IFC-CAF ${ }^{\circledR}$ caused attenuation of the expression of $\mathrm{CycE}$ and the DNA damage marker, $\gamma \mathrm{H} 2 \mathrm{AX}$ (indicative of protected genomic integrity Figure $4 \mathrm{C}, \mathrm{D}$ ).

\subsection{IFC-CAF ${ }^{\circledR}$ Improves Telomere Maintenance}

Since short-term treatment with IFC-CAF ${ }^{\circledR}$ caused a reversible effect on proliferation (Figure 2), we investigated whether replicative aging of stem cells in the presence of IFC$\mathrm{CAF}^{\circledR}$ was being diminished or enhanced. We have established in vitro models informative for the process of aging and loss of proliferative potential in primary keratinocytes [21]. We tested the impact of long-term exposure to IFC-CAF ${ }^{\circledR}$ in stem cells aged by replicative exhaustion. In our model, primary keratinocytes were cultured for 24 days through two very low-density passages (see Material and Methods). After exhaustion control stem cells exhibited a reduction in proliferation by $\sim 45 \%(p<0.01)$ (Figure $5 \mathrm{~A}, \mathrm{~B})$. The supplementation with $0.9 \mathrm{mg} / \mathrm{mL}$ IFC-CAF ${ }^{\circledR}$ did not significantly affect the proliferative capacity of aged stem cells (CT aged) (Figure 5A,B) $(p>0.05)$.

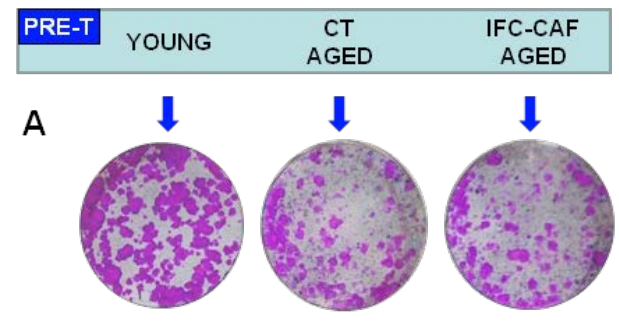

B

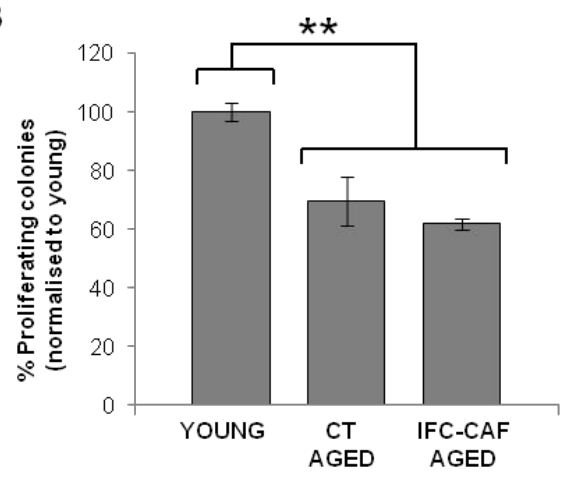

Figure 5. IFC-CAF ${ }^{\circledR}$ does not rescue replicative decline of epidermal stem cells. (A) Representative clonogenicity assays with young keratinocytes or keratinocytes that were aged for 24 days in the presence or absence of $0.9 \mathrm{mg} / \mathrm{mL}$ IFC-CAF ${ }^{\circledR}$ as indicated (PRE-T), then plated in the absence of the compound. (B) Proportion of proliferative colonies (normalised to young keratinocytes) across the indicated conditions from two independent experiments with duplicate samples. Statistical significance was assessed by Student's $t$ test $(* *: p<0.01)$.

In addition to proliferative capacity, a hallmark of replicative aging is the shortening of the telomeres of the stem cells [2]. We established quantitative fluorescent in situ hybridisation procedures (Q-FISH) capable of capturing changes in telomere length during replicative aging of primary epidermal keratinocytes [2]. Aged keratinocytes showed an average reduction of $\sim 50 \%$ in total telomere signal, as compared to non-aged control cultures (Figure 6). Interestingly, despite the reversible association with a modest reduction 
in proliferative potential, IFC-CAF ${ }^{\circledR}$ supplementation attenuated the telomere effect of aging on genome integrity by $15 \%$ (i.e., a blunting on the telomere shortening effect of aging by $\sim 30 \%\left(^{* *}: p<0.01, \mathrm{n}>16\right.$ ), indicating that the treatment protected stem cells from telomere-associated aging (Figure 6).

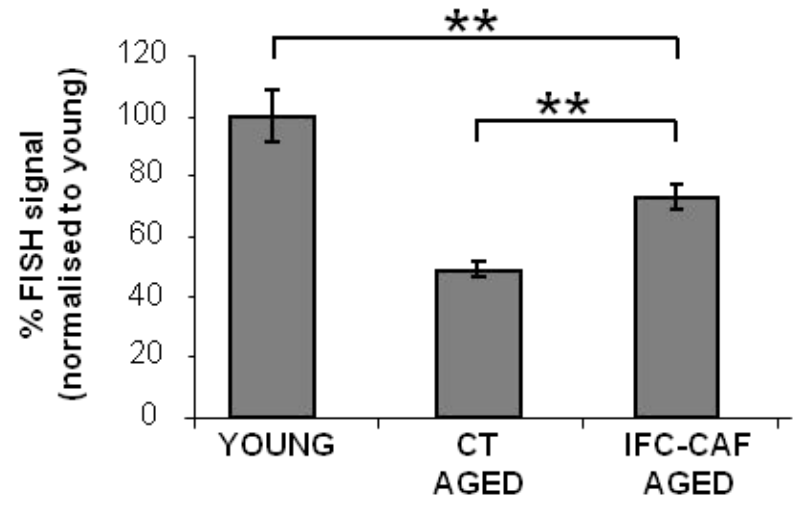

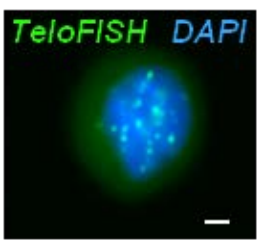

YOUNG

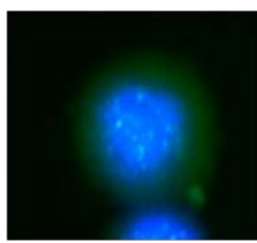

CT AGED

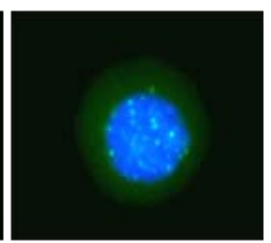

IFC-CAF

AGED

Figure 6. IFC-CAF ${ }^{\circledR}$ protects aging stem cells from telomeric shortening. TeloFISH quantitative imaging of either 'young' keratinocytes, keratinocytes aged for 24 days, or aged keratinocytes supplemented with $0.9 \mathrm{mg} / \mathrm{mL}$ (representative micrographs in bottom panels; scale bar: $2 \mu \mathrm{m}$ ), representative of two independent experiments (bar histogram). Data are represented as percent of signal relative to young keratinocytes. Statistical significance was assessed by Student's $t$ test $(* *: p<0.01)$.

\section{Discussion}

Increased life expectancy and a variety of sources of environmental stressors-including UV exposure from lifestyle changes-are associated with skin aging in modern societies [22,23]. Identifying non-toxic compounds capable of blocking or even reversing these effects is therefore warranted, as either suppliers of protective antioxidant molecules, activators of endogenous defences, or modulators of regeneration events. Among natural compounds with the capability of boosting skin repair and homeostasis restoration, extracts from the $C$. aspersa snail have received attention. In this study, we inquired whether IFC-CAF ${ }^{\circledR}$, a preparation from C. aspersa eggs, modulates distinct aspects of the biology of primary keratinocytes, which directly determine skin regeneration. Our observations support a model whereby IFC-CAF ${ }^{\circledR}$ favours the mobilization and stratified differentiation of epidermal stem cell precursors, while potentiating genome integrity surveillance mechanisms that allow DNA repair and prevent telomere shortening during aging. In addition, we observed an attenuation in cell cycle progression, associated with a partial stalling in the G2 phase. However, pre-treatment with IFC-CAF ${ }^{\circledR}$ did not cause loss of proliferative potential, indicating that the deceleration of the cell cycle was reversible and was not due to terminal differentiation or senescence of the stem cells.

In vitro cultures of primary keratinocytes are hyperproliferative, as they are stimulated by serum and growth factors [17]. The results all together are consistent with IFC-CAF ${ }^{\circledR}$ counterbalancing hyperproliferation to preserve orderly cycling and steady-state proliferation. p53 (referred to as 'the guardian of the genome') by inducing CDK inhibitors 
such as p21CIP, slows down the cell cycle at the G1/S and G2/M transitions to allow DNA repair [24]. In keratinocytes, the G2/M transition is critical to cell fate [25,26]. In contrast, Cyclin $\mathrm{E}$ is the main drive of the cell cycle by activating CDK2 and when overexpressed causes replication stress and DNA damage [27]. Therefore, IFC-CAF ${ }^{\circledR}$ might protect genome integrity and the regenerative potential of keratinocytes by inducing p53 and prolonging the DNA repair phase at G2. As a result, Cyclin E was down-regulated by IFC-CAF ${ }^{\circledR}$. Reduced levels of Cyclin $\mathrm{E}$ together with up-regulation of p53 and attenuation of the DNA marker $\gamma \mathrm{H} 2 \mathrm{AX}$, are consistent with tighter control of the cycle. In turn, this is consistent with a more timely homeostatic coordination between the cell cycle and DNA repair, cell division and differentiation, resulting in better protection of genome integrity.

Additional pathways might relate to the mechanisms by which IFC-CAF ${ }^{\circledR}$ drives a differentiated phenotype and enhances genome integrity surveillance networks. Epidermal differentiation-as for other related phenomena whose sensitivity to IFC-CAF ${ }^{\circledR}$ has been studied, such as fibroblast secretory phenotype promotion, extracellular matrix deposition and mesenchymal differentiation $[1,12-14]$ - is a process that engages cell homeostasis surveillance systems such as the Unfolded Protein Response (UPR) [28-32]. This network directly enhances the protein synthesis capacity of cells [29] but also engages in reciprocal crosstalk with mechanisms such as the DNA damage response $[29,33]$ that prime cells with increased protein synthesis and secretion demand for confronting potential derived oxidative stress and damage. In addition, reversible stalling of the cell cycle at G2/M is a conserved feature directly controlled by UPR effectors across eukaryotic clades $[5,19,33-36]$. The precise mechanisms by which this occurs are unknown, but given that $C$. aspersa egg extracts exhibit the property of promoting ordered, physiological differentiation in a variety of cell types [12,13], it is plausible that growth factor components play a significant role. Importantly, IFC-CAF ${ }^{\circledR}$ induced genome integrity surveillance-which is effective as correlates with reduced age-induced telomere shortening (described in this study) and protection from UV-induced DNA damage [13] — in the absence of senescence and without subsequent reduction of the proliferative potential, a feature of homeostatic adaptation [2] Although long treatment with IFC-CAF ${ }^{\circledR}$ did not rescue replicative aging while present, the treatment protected telomere length, indicative of maintenance of genome integrity.

In conclusion, we interpret that IFC-CAF ${ }^{\circledR}$ engages, concomitantly with differentiation programmes, homeostatic surveillance networks including genome integrity surveillance orchestrated by p53 and hallmarks of cell cycle progression reduction. This would explain the reduced accumulation of $\gamma \mathrm{H} 2 \mathrm{AX}$ in IFC-CAF ${ }^{\circledR} /$ treated cells as compared to untreated cells, supporting the notion that IFC-CAF ${ }^{\circledR}$ engages mechanisms that ensure genome integrity and contributes to reducing insults conductive to cell aging. Our study provides evidence that induction of ordered epithelial differentiation and activation of protective defence responses against cell damage in skin stem cell precursors are specific components of the activity of IFC-CAF ${ }^{\circledR}$ in skin regeneration and health. Future research will determine further molecular principles of this activity and the potential synergy in skin repair and regeneration when combined with compounds that promote the proliferation of skin stem cell pools.

\section{Materials and Methods}

\subsection{Reagents}

IFC-CAF ${ }^{\circledR}$ eggs extract contains proteins, proteoglycans, glycosaminoglycans, polysaccharides, mineral salts and water, and was prepared according to the US patent 20120107410A1 and described by Espada et al., [13]. Briefly, gastropod spawns were washed with distilled water at a very low pressure, immersed in saline solution between $2{ }^{\circ} \mathrm{C}$ and $8{ }^{\circ} \mathrm{C}$. Then, the saline solution was filtered through a $3 \mathrm{~mm}$ mesh to obtain intact snail spawn remain. After the lysis and homogenisation of the spawn with a Silverson mill, it was filtered again. The resulting liquid was obtained at a concentration of protein of $27 \mathrm{mg} / \mathrm{mL}$ and it was used in this work at the indicated concentrations. 


\subsection{Cell Culture}

Primary human keratinocytes (stem cells, cells committed to differentiate and differentiating cells) were isolated from neonatal foreskin and cultured in Rheinwald medium (Ham's F12 medium/ Dulbecco's Modified Eagle Medium (DMEM) (1:3), $1.8 \times 10^{-4} \mathrm{M}$ adenine) supplemented with $10 \%$ Fetal Bovine Serum (FBS), $0.5 \mu \mathrm{g} / \mathrm{mL}$ of hydrocortisone, $5 \mu \mathrm{g} / \mathrm{mL}$ of insulin, $10^{-10} \mathrm{M}$ cholera enterotoxin and $10 \mathrm{ng} / \mathrm{mL}$ of epidermal growth factor $\left(1.2 \mathrm{mM} \mathrm{Ca}^{+2}\right)$ [17]. Mouse fibroblast 3T3 J2 were treated with mitomycin C (MC) for two hours to suppress proliferation and used as a feeder layer. Cells were routinely tested for mycoplasma contamination and were always negative. Low passages [1-4] of keratinocytes from two different donors were utilised along the study. Note that only stem cells have a great potential to proliferate and amplify into a large population of cells.

For clonogenicity assays, 2500 keratinocytes were plated per T6 well triplicates in Rheinwald flavin adenine dinucleotide medium. About 12 days later, the cultures were fixed with 3.7\% formaldehyde (Sigma-Aldrich, San Luis, Misuri, USA; F8775) for $10 \mathrm{~min}$, rinsed with 1X PBS and stained with rhodamine-Nile blue solution (1\% Rhodamine B [Sigma-Aldrich, San Luis, Misuri, USA; R6626]; 1\% Nile Blue A [Sigma-Aldrich, San Luis, Misuri, USA; N5632]) as previously described [17]. Within this assay, large colonies are founded by individual stem cells, whereas cells committed to differentiate give rise to nearly microscopic colonies (about 32 cells) and differentiating cells give no colonies at all [16].

\subsection{Antibodies}

The following primary antibodies from Santa Cruz Biotechnology (Dallas, TX, USA) were used: anti-Cyclin E1 (mouse monoclonal, HE12, sc-247, lot H2511; Western Blot, WB), anti-glyceraldehyde 3-phosphate dehydrogenase (GAPDH, rabbit polyclonal, FL-335, sc-25778; WB), anti-p53 (FL-393, rasdfef. sc-6243; WB). The following primary antibodies were used from Sigma-Aldrich (San Luis, MO, USA): anti-involucrin (mouse monoclonal, SY5, I-9018, lot 071M4784; immunofluorescence, IF, flow cytometry, FC and WB), anti-IgG (mouse, I-5381; FC). Anti- $\gamma \mathrm{H} 2 \mathrm{AX}$ antibody was mouse monoclonal, JBW301, 05-636-I, lot 1997719, from Millipore (Burlington, MA, USA; IF, FC and WB).

The following secondary antibodies were used from Jackson ImmunoResearch (West Grove, PA, USA): Alexa Fluor ${ }^{\circledR}$ 488-conjugated goat polyclonal anti rabbit (111-547-003) or anti mouse (115-547-003) IgG antibodies (FC and IF). HRP-conjugated goat anti rabbit (170-6515) or anti mouse (170-6516) IgG antibodies from BioRad (Hercules, CA, USA; WB).

\subsection{Flow Cytometry}

Keratinocytes were harvested by trypsin, washed with PBS, fixed and labelled for DNA content or involucrin detection as described previously [37]. Briefly, for involucrin staining, cells were fixed in 3.7\% paraformaldehyde (ref. 158127, Sigma-Aldrich, San Luis, MO, USA), and permeabilised with cold 6\% saponin (ref. S4521, Sigma-Aldrich, San Luis, MO, USA) PBS for $20 \mathrm{~min}$ at RT. Cells were then incubated with anti-involucrin (SY5) in cold PSF buffer (0.2\% saponin, $0.5 \%$ FBS in PBS), washed and incubated with the secondary anti mouse AlexaFluor ${ }^{R}$ 488. A similar concentration of isotype-negative immunoglobulins (mouse IgGs) was included as negative control for antibody staining. For DNA content, cells were stained with Propidium iodide (PI, $25 \mu \mathrm{g} / \mathrm{mL}$, Life-Technologies, overnight). In all cases, after staining, cells were firmly resuspended and filtered through a $70 \mu \mathrm{M}$ mesh to avoid aggregates. For analysis, a Becton Dickinson FACSCanto ${ }^{\mathrm{TM}}$ cytometer (Franklin Lakes, NJ, USA) was used, 10,000 events were gated and acquired in the mode list.

\subsection{Confocal Microscopy}

Keratinocytes were grown on glass coverslips, fixed and stained as previously described [25]. Z-stack 3D digital images were reconstructed after frame collection by confocal microscopy (Nikon A1R, Melville, NY, USA; $20 \times$ numerical aperture (NA) 0.75 ) and processed by NIS Elements software (AR, 3.264 bits; Nikon). Frames were collected every 
$2 \mu \mathrm{m}$ in the $\mathrm{Z}$ axis, which was scaled up 0.5 times (to $1.5 \mu \mathrm{m}$ ). Images were captured from three-dimensional confocal reconstruction videos.

\subsection{Whole-Cell Extracts and Western Blotting}

Cells were harvested by trypsin and pellets were incubated for $10 \mathrm{~min}$ in cold lysis buffer (100 mM NaCl, $50 \mathrm{mM}$ Tris p H7,5, $10 \mathrm{mM}$ EDTA, 1\% NP40, $2.5 \mathrm{mM} \mathrm{NaPPi}, 5 \mathrm{mM}$ $\mathrm{NaF}, 2.5 \mathrm{mM} \beta$-glycerophosphate, $1 \mathrm{mM}$ DTT supplemented with protease inhibitors of Boehringer, Ingelheim am Rhein, Germany). Then, cells were mixed by pipetting and digested by 3 rounds of 5 min sonication. The supernatant was collected as a soluble fraction and total protein quantification was carried out by a fluorometric system Qubit 4.0 (Life Technologies, Carlsbad, California, USA). $80 \mu \mathrm{g}$ of protein were subjected to sodium dodecyl sulfate-polyacrylamide gel electrophoresis and transferred to nitrocellulose membranes. Membranes were blocked with TTBS- 5\% milk for $1 \mathrm{~h}$ at RT, incubated overnight with primary antibodies at $4{ }^{\circ} \mathrm{C}$, washed twice with TTBS for $15 \mathrm{~min}$ and incubated with the corresponding secondary antibodies for $1 \mathrm{~h}$ at room temperature. Enhanced chemiluminescence substrate (Lumi-Light ${ }^{\mathrm{TM}}$, Roche Applied Science, Penzberg, Germany) or Odyssey Infrared Imaging System (Li-cor) was used for antibody detection. For detection of involucrin in the highly insoluble cellular fraction, the resultant pellet after lysis was incubated in Urea buffer (10 mM Tris pH 8, 5\% SDS, 5\% $\beta$-mercaptoethanol, $4 \mathrm{M}$ Urea [38]. In this case, same number of cells was loaded onto the gel in all lanes (8000).

\subsection{Replicative Aging of Keratinocytes}

Freshly isolated keratinocytes (young) were subjected to two serial passages at very low density ( 2500 cells per T6 well), for replicative exhaustion, in Rheinwald medium supplemented or not with $0.9 \mathrm{mg} / \mathrm{mL}$ IFC-CAF ${ }^{\circledR}$. After 24 days in culture, young and aged cells were harvested and plated for clonogenicity assays in the absence of IFC-CAF ${ }^{\circledR}$, or fixed for telomere length analyses.

\subsection{Telomere Length Analysis}

Pellets of $10^{6}$ cells were washed twice with $0.1 \%$ BSA PBS and resuspended in $500 \mu \mathrm{L}$ of hybridisation buffer $(20 \mathrm{mM}$ Tris- $\mathrm{HCl} \mathrm{pH} \mathrm{7.2,} \mathrm{70 \%} \mathrm{deionised} \mathrm{formamide,} 1 \% \mathrm{BSA}, 0.6 \%$ FITC-PNA probe). For negative control, FITC-PNA probe was not added. Samples were denaturalised at $80^{\circ} \mathrm{C} 10$ min under agitation and incubated for $2 \mathrm{~h}$ at room temperature in the dark. Samples were then washed twice with PBS 0.1\% BSA and pellets were resuspended in $500 \mu \mathrm{L}$ of buffer I ( $20 \mathrm{mM}$ Tris-HCL 7.2, 70\% deionised FMDA, $0.1 \%$ BSA, $0.1 \%$ Tween 20, 1\% FCS). After centrifugation, pellets were resuspended in $500 \mu \mathrm{L}$ of buffer II $(0.1 \%$ BSA, $0.1 \%$ Tween $20,1 \%$ FCS). Finally, samples were centrifuged and pellets were resuspended in 50-100 $\mu \mathrm{L}$ of $1 \mathrm{X}$ PBS and mounted in slides with the Gold antifade Reagent prolonged mounting medium with DAPI (Thermo Fisher Scientific, Waltham, MA, USA; P10144). They were visualised and photographed through an ECLIPSE TS100F microscope equipped with a LEDCMOS 5MPCOLOR camera (Nikon, Minato, Tokyo, Japan).

Author Contributions: Conceptualisation, S.G., A.G. (Antonio Guerero) and A.G. (Alberto Gandarillas); methodology, A.G. (Antonio Guerero), I.d.P. and A.G. (Alberto Gandarillas); software, L.S.J., I.d.P. and A.G. (Alberto Gandarillas); validation, S.G., A.G. (Alberto Gandarillas) and A.R.-L.; formal analyses, L.S.J., I.d.P. and A.G. (Alberto Gandarillas); investigation, L.S.J., I.d.P. and A.G. (Alberto Gandarillas); data curation, L.S.J., I.d.P. and A.G. (Alberto Gandarillas); writing-original draft preparation, A.G. (Alberto Gandarillas). and A.R.-L.; writing-review and editing, L.S.J., A.R.-L., M.V., A.G. (Antonio Guerero) and A.G. (Alberto Gandarillas).; supervision, A.G. (Antonio Guerero) and A.R.-L. and A.G. (Alberto Gandarillas); project administration, M.V., A.R.-L. and A.G. (Alberto Gandarillas); funding acquisition, A.G. (Alberto Gandarillas), A.R.-L. and S.G. All authors have read and agreed to the published version of the manuscript.

Funding: This research was supported by Cantabria Labs (Spain). 
Institutional Review Board Statement: The study was conducted according to the guidelines of the Declaration of Helsinki and approved by the Ethical Committee for Clinical Research of Cantabria Council (2011.062, April 2011), Spain.

Informed Consent Statement: In all cases, human tissue material discarded after surgery was obtained with written consent presented by clinicians to the patients, and it was treated anonymously.

Acknowledgments: We thank Alicia Noriega and Laura Ceballos for technical assistance and Arancha Delgado for support. Miguel Sánchez-Álvarez provided assistance for manuscript preparation and editing. Cantabria Labs funded this study. LSJ was supported by University of Cantabria/IDIVAL (PREVAL 19/06).

Conflicts of Interest: S.G. has a consultant role for Cantabria Labs, A. R.-L., A.Gue., and M.V. belong to the Innovation and Development and Medical Affairs Department, respectively, at Cantabria Labs, which produced IFC-CAF ${ }^{\circledR}$. The remaining authors declare no conflict of interest.

\section{References}

1. Sundaram, H. The mechanisms and potential impact of stem cell activation in skin rejuvenation: An evidence-based analysis. J. Drugs Dermatol. 2017, 16, 378-384. [PubMed]

2. López-Otín, C.; Blasco, M.A.; Partridge, L.; Serrano, M.; Kroemer, G. The hallmarks of aging. Cell 2013, 153, 1194-1217. [CrossRef]

3. Lopez-Otin, C.; Galluzzi, L.; Freije, J.M.P.; Madeo, F.; Kroemer, G. Metabolic Control of Longevity. Cell 2016, $166,802-821$. [CrossRef] [PubMed]

4. Lu, M.C.; Ji, J.A.; Jiang, Z.Y.; You, Q.D. The Keap1-Nrf2-ARE Pathway As a Potential Preventive and Therapeutic Target: An Update. Med. Res. Rev. 2016, 36, 924-963. [CrossRef]

5. Brewer, J.W.; Diehl, J.A. PERK mediates cell-cycle exit during the mammalian unfolded protein response. Proc. Natl. Acad. Sci. USA 2000, 97, 12625-12630. [CrossRef] [PubMed]

6. $\quad$ Lorrio, S.; Rodríguez-Luna, A.; Delgado-Wicke, P.; Mascaraque, M.; Gallego, M.; Pérez-Davó, A.; González, S.; Juarranz, Á. Protective effect of the aqueous extract of Deschampsia antarctica (EDAFENCE ${ }^{\circledR}$ ) on skin cells against blue light emitted from digital devices. Int. J. Mol. Sci. 2020, 21, 988. [CrossRef]

7. Ortiz-Espin, A.; Morel, E.; Juarranz, A.; Guerrero, A.; Gonzalez, S.; Jimenez, A.; Sevilla, F. An Extract from the Plant Deschampsia antarctica Protects Fibroblasts from Senescence Induced by Hydrogen Peroxide. Oxid. Med. Cell. Longev. 2017, 2017, 2694945. [CrossRef]

8. Milani, M.; Hashtroody, B.; Piacentini, M.; Celleno, L. Skin protective effects of an antipollution, antioxidant serum containing Deschampsia antartica extract, ferulic acid and vitamin C: A controlled single-blind, prospective trial in women living in urbanized, high air pollution area. Clin. Cosmet. Investig. Dermatol. 2019, 12, 393-399. [CrossRef] [PubMed]

9. Gombau, L.; García, F.; Lahoz, A.; Fabre, M.; Roda-Navarro, P.; Majano, P.; Alonso-Lebrero, J.L.; Pivel, J.P.; Castell, J.V.; GomezLechon, M.J.; et al. Polypodium leucotomos extract: Antioxidant activity and disposition. Toxicol. In Vitro 2006, 20 , 464-471. [CrossRef]

10. Gonzalez, S.; Gilaberte, Y.; Philips, N.; Juarranz, A. Fernblock, a Nutriceutical with Photoprotective Properties and Potential Preventive Agent for Skin Photoaging and Photoinduced Skin Cancers. Int. J. Mol. Sci. 2011, 12, 8466-8475. [CrossRef]

11. Brieva, A.; Philips, N.; Tejedor, R.; Guerrero, A.; Pivel, J.P.; Alonso-Lebrero, J.L.; Gonzalez, S. Molecular basis for the regenerative properties of a secretion of the mollusk Cryptomphalus aspersa. Skin Pharmacol. Physiol. 2008, 21, 15-22. [CrossRef]

12. Alameda, M.T.; Morel, E.; Parrado, C.; González, S.; Juarranz, Á. Cryptomphalus aspersa mollusc egg extract promotes regenerative effects in human dermal papilla stem cells. Int. J. Mol. Sci. 2017, 18, 463. [CrossRef] [PubMed]

13. Espada, J.; Matabuena, M.; Salazar, N.; Lucena, S.; Kourani, O.; Carrasco, E.; Calvo, M.; Rodriguez, C.; Reyes, E.; Gonzalez, S.; et al. Cryptomphalus aspersa mollusc eggs extract promotes migration and prevents cutaneous ageing in keratinocytes and dermal fibroblasts in vitro. Int. J. Cosmet. Sci. 2015, 37, 41-55. [CrossRef] [PubMed]

14. Draelos, Z.D. The Role of a Natural Mollusk Egg-Derived Ingredient in Facial Appearance. J. Drugs Dermatol. 2017, 16, 678-681. [PubMed]

15. García-Honduvilla, N.; Cifuentes, A.; Ortega, M.A.; Delgado, A.; González, S.; Bujan, J.; Alvarez-Mon, M. High Sensitivity of Human Adipose Stem Cells to Differentiate into Myofibroblasts in the Presence of C. aspersa Egg Extract. Stem Cells Int. 2017, 2017, 9142493. [CrossRef]

16. Jones, P.H.; Watt, F.M. Separation of human epidermal stem cells from transit amplifying cells on the basis of differences in integrin function and expression. Cell 1993, 73, 713-724. [CrossRef]

17. Rheinwald, J.G. Human epidermal keratinocyte cell culture and xenograft systems: Applications in the detection of potential chemical carcinogens and the study of epidermal transformation. Prog. Clin. Biol. Res. 1989, 298, 113-125. [PubMed]

18. Bayerl, C.; Taake, S.; Moll, I.; Jung, E.G. Characterization of sunburn cells after exposure to ultraviolet light. Photodermatol. Photoimmunol. Photomed. 1995, 11, 149-154. [CrossRef]

19. Henry, K.A.; Blank, H.M.; Hoose, S.A.; Polymenis, M. The unfolded protein response is not necessary for the G1/S transition, but it is required for chromosome maintenance in Saccharomyces cerevisiae. PLoS ONE 2010, 5, e12732. [CrossRef] 
20. Fragkos, M.; Jurvansuu, J.; Beard, P. H2AX is required for cell cycle arrest via the p53/p21 pathway. Mol. Cell. Biol. 2009, 29, 2828-2840. [CrossRef]

21. Freije, A.; Molinuevo, R.; Ceballos, L.; Cagigas, M.; Alonso-Lecue, P.; Rodriguez, R.; Menendez, P.; Aberdam, D.; De Diego, E.; Gandarillas, A. Inactivation of p53 in Human Keratinocytes Leads to Squamous Differentiation and Shedding via Replication Stress and Mitotic Slippage. Cell Rep. 2014, 9, 1349-1360. [CrossRef] [PubMed]

22. Vermeulen, R.; Schymanski, E.L.; Barabasi, A.-L.; Miller, G.W. The exposome and health: Where chemistry meets biology. Science 2020, 367, 392-396. [CrossRef] [PubMed]

23. Krutmann, J.; Bouloc, A.; Sore, G.; Bernard, B.A.; Passeron, T. The skin aging exposome. J. Dermatol. Sci. 2017, 85, 152-161. [CrossRef] [PubMed]

24. Aylon, Y.; Oren, M. p53: Guardian of ploidy. Mol. Oncol. 2011, 5, 315-323. [CrossRef]

25. Molinuevo, R.; Freije, A.; Contreras, L.; Sanz, J.R.; Gandarillas, A. The DNA damage response links human squamous proliferation with differentiation. J. Cell Biol. 2020, 219, e202001063. [CrossRef]

26. Sanz-Gómez, N.; de Pedro, I.; Ortigosa, B.; Santamaría, D.; Malumbres, M.; de Cárcer, G.; Gandarillas, A. Squamous differentiation requires G2/mitosis slippage to avoid apoptosis. Cell Death Differ. 2020, 27, 2451-2467. [CrossRef] [PubMed]

27. Teixeira, L.K.; Reed, S.I. Cyclin E Deregulation and Genomic Instability. Adv. Exp. Med. Biol. 2017, 1042, $527-547$.

28. Feng, Y.X.; Sokol, E.S.; Del Vecchio, C.A.; Sanduja, S.; Claessen, J.H.L.; Proia, T.A.; Jin, D.X.; Reinhardt, F.; Ploegh, H.L.; Wang, Q.; et al. Epithelial-to-mesenchymal transition activates PERK-eIF2 $\alpha$ and sensitizes cells to endoplasmic reticulum stress. Cancer Discov. 2014, 4, 702-715. [CrossRef]

29. Hetz, C.; Zhang, K.; Kaufman, R.J. Mechanisms, regulation and functions of the unfolded protein response. Nat. Rev. Mol. Cell Biol. 2020, 21, 421-438. [CrossRef]

30. Yeo, S.Y.; Lee, K.W.; Shin, D.; An, S.; Cho, K.H.; Kim, S.H. A positive feedback loop bi-stably activates fibroblasts. Nat. Commun. 2018, 9, 3016. [CrossRef]

31. Walter, P.; Ron, D. The unfolded protein response: From stress pathway to homeostatic regulation. Science 2011, 334, 1081-1086. [CrossRef]

32. Sanchez-Alvarez, M.; Bakal, C. PERK links the clock and protein stress in cancer. Nat. Cell Biol. 2018, 20, 4-5. [CrossRef] [PubMed]

33. Dufey, E.; Bravo-San Pedro, J.M.; Eggers, C.; Gonzalez-Quiroz, M.; Urra, H.; Sagredo, A.I.; Sepulveda, D.; Pihán, P.; CarrerasSureda, A.; Hazari, Y.; et al. Genotoxic stress triggers the activation of IRE1alpha-dependent RNA decay to modulate the DNA damage response. Nat. Commun. 2020, 11, 2401. [CrossRef]

34. Sanchez-Alvarez, M.; Zhang, Q.; Finger, F.; Wakelam, M.J.O.; Bakal, C. Cell cycle progression is an essential regulatory component of phospholipid metabolism and membrane homeostasis. Open Biol. 2015, 5, 150093. [CrossRef] [PubMed]

35. Hollien, J. Evolution of the unfolded protein response. Biochim. Et Biophys. Acta-Mol. Cell Res. 2013, 1833, 2458-2463. [CrossRef]

36. Sequeira, S.J.; Ranganathan, A.C.; Adam, A.P.; Iglesias, B.V.; Farias, E.F.; Aguirre-Ghiso, J.A. Inhibition of proliferation by PERK regulates mammary acinar morphogenesis and tumor formation. PLoS ONE 2007, 2, e615.

37. Sanz-Gómez, N.; Freije, A.; Gandarillas, A. Keratinocyte Differentiation by Flow Cytometry. Methods Mol. Biol. 2020, 2109 , 83-92. [PubMed]

38. Achtstaetter, T.; Hatzfeld, M.; Quinlan, R.A.; Parmelee, D.C.; Franke, W.W. Separation of cytokeratin polypeptides by gel electrophoretic and chromatographic techniques and their identification by immunoblotting. Methods Enzymol. 1986, 134, 355-371. 